\title{
US quarantine rules attacked
}

\section{Washington}

US BIOTECHNOLOGY companies are hoping to persuade the US Department of Agriculture (USDA) to bend its notoriously strict quarantine rules that delay for up to a year the importation of cell lines and cellline products. The companies complain that unless an exemption is granted, the United States could find itself at a competitive disadvantage in world markets. Industry experts claim that within a few years, US companies will be seeking to import thousands of tissue cultures, hybridomas and tissue-culture products every year.

The USDA quarantine applies to any material prepared with animal products that could harbour the foot-and-mouth disease virus or other livestock diseases not already found in the United States. For the biotechnology industry, this typically means products prepared with bovine serum or the enzyme trypsin, which is obtained from cows or pigs. All imports must go through safety testing at USDA's Plum Island quarantine facility before being allowed into the country. Companies must pay for the test, which usually costs around $\$ 2,500$.

Bruce Mackler, general counsellor for the Association of Biotechnology Companies, says that the rules are having an immediate effect on US companies such as Charles River and Damon that are hoping to compete with European companies, notably Celltech in Britain, in the contract fermentation business.

According to Dr Laura Peterson of USDA's Animal and Plant Health Inspection Service, about 100 applications for import permits are filed each year. She said that there has been a noticeable trend among the applications from biotechnology companies towards requests for importing large numbers of hybridomas at a time.

Peterson said she did not know of any cases so far in which biotechnology products had been found to carry disease organisms. But one of the nine outbreaks of foot-and-mouth disease that occurred in the United States between 1870 and 1929 was traced to an imported smallpox vaccine. Foot-and-mouth disease is present in France, Germany, Switzerland and other mainland European countries; it has been eliminated in the United Kingdom, Scandinavia and Japan. Foot-and-mouth is a special case under US law: importation of the virus for any purpose is forbidden. Testing involves inoculating a steer at Plum Island followed by serological testing after 4-6 weeks. A number of less common livestock diseases found in Australia and Africa are also of concern to USDA, but these can generally be spotted with simpler tissue-culture tests.

Peterson indicated that USDA was sympathetic to the industry's concern; one pos- sibility would be to exempt from safety testing products that will be used in clinical applications or as in vitro diagnostics, where the risk of spread to livestock is small so long as used material is properly disposed of. The industry is also trying to encourage development of a tissue-culture test for foot-and-mouth, and is proposing to support a postdoctoral worker at Plum Island to assist in this work; Peterson said that USDA was cooperating in this effort.
Industry representatives are meeting USDA officials this week, and a decision is expected soon on new procedures.

Academic research, in which laboratory animals are used, poses a more difficult problem, one compounded by widespread ignorance of or indifference to the regulations by academics. Mackler notes that "casual transfers" of cell lines have been the norm for years among academic researchers, who are accustomed to putting samples "in their pockets" and blithely walking through customs; no company could take the risk of following that example.

\section{CERN economics}

\section{Particle physics pays (official)}

THE European Organisation for Nuclear Research, CERN (near Geneva), can claim to pay back at least 60 per cent of its current $£ 240$ million annual budget in the form of "added value" from its contracts with European industry, claims a CERN report just published*, CERN made a similar study, and claim, for the first time ten years ago. The present report brings the story up to date, projects value forward to 1987 and may be of significance in the struggle over the CERN budget in Britain.

Dr Herwig Schmeid, now an economist at the University of Strasbourg, pioneered the methods the report uses - basically a series of interviews with a random sample of CERN contractors, who were asked to quantify any spin-off from CERN work. Lowest values were always taken, CERN claims, and when the benefit was unquantifiable (such as the prestige of a CERN contract when seeking new clients), "no benefit" was recorded. So the method underestimates spin-off, claims CERN personnel manager Dr Norman Blackburne, one of the co-authors of the new report. It also ignores the actual value of the CERN contract itself.

CERN agreed with the companies investigated that they would not be named, but the report includes some examples of the added value, or "economic utility" as CERN describes it, of CERN contracts, such as the shipyard that contracted for some of the heavy steel work required for the big collision detectors on the CERN proton-antiproton collider. The yard increased the precision of its manufacturing and was able to contract successfully for work on North Sea oil rigs, say Blackburne, and it was also able to avoid laying off some of its workers during a slack period at the yard. But the net benefit to the company was considered unquantifiable, and so not counted in the report.

Analysed by sector of industry, electronics, optics and computing gained most utility from CERN. Over 1973-82, 57 companies interviewed gained six times the value of their CERN contracts in new contracts outside CERN. Sixteen steel and welding companies gained more than five times, and 22 vacuum, cryogenics and superconductivity suppliers three times. Electrical equipment and precision mechanics manufacturers doubled the value of their contracts, the report claims.

One company, not named but probably the Norwegian computer company NorskData, considered its prospects transformed by a large contract to supply the control system for the Super Proton Synchrotron. Another company, employing 50 people, was created just to supply CERN with flanges and clamps for connecting vacuum pipes; it developed a "highly suitable alloy", flexible and radiation-resistant, and from being wholly dependent on CERN now exports 70 per cent of its production.

In general, many companies have used CERN to help them cover the costs of development of a risky new product; or, in one case, where a company was manufacturing racks for electronics, CERN requirements provided an ever-improving standard that enabled the company to beat the competition in more mundane settings such as telecommunications and signalling.

But, says Blackburne, there was no single glamorous breakthrough attributable to CERN contracts: rather an accumulation of expertise. (And in one case, the report admits, the value was negative, where the exacting CERN specifications caused a company to restructure towards providing quality levels that other customers did not require.)

The previous pioneering CERN report on economic utility was criticized for lack of rigour, "but this time we have been extremely strict with our sampling process", says Blackburne. The chief conclusion of the report is that one Swiss Franc spent by CERN on high technology between 1972 and 1983 generated or will generate three Swiss Francs of "economic utility" in 1972-87. The overall cost of the organization in 1972-83 was SF 6,945 million (around $£ 2,300$ million), and the estimated economic utility SF 4,800 (around $£ 1,600$ million), or 60 per cent of costs.

Robert Walgate

*Economic utility arising from CERN contracts (second study), CERN yellow report 84-14. 